\title{
Confusing Violent People with Violent Places: An Investigation of Urban Change and Criminality in Port Harcourt
}

\author{
${ }^{1}$ Ekpenyong, Nkereuwem Stephen (Ph.D), ${ }^{2}$ Yong A. Nkpha \\ Department Of Sociology, Niger Delta University, Wilberforceisland, Bayelsa State \\ Doctorial Student Depertment Of Socialogy Faculty Of Social Sciences University Of Port Harcourt
}

\begin{abstract}
Indeed some works on urban settlement and crime are skeptical that specific places can be considered a category capable of differentiating social groups base on their controversial status in other subareas of sociology, the twin concept of study of crime and urban communities remain important. Social inequality that shared perceptions of social deprivation have been instrumental in creating a distinct community based collective psychological reaction. It is this specific psychological reaction which in theory has made shanty dwellers more aggressive than non-shanty dwellers. In this paper, we show how spatial inequality goes about constructing difference based on a collective psychological reaction to social deprivation. To do this, the study used some assumptions on key variable 'crime', income' and 'class'. Using regress and regression micro fit 4.1 statistical package, the study revealed that crime in Port Harcourt is not tied to spatial phenomenon but based on the prevalence of certain social forces which determine the dimension and magnitude of crime. The study recommends the inclusion of urban poor in government housing development plan.
\end{abstract}

Key woeds: Violent, People, Violent Places', Urban, Change, Criminality, Port Harcourt.

\section{Conceptual Background}

Obviously, many of the problems that plague spatial theories stem from their need to infer a collective psychological reaction which predisposes youths of certain area to become involved in violent outbursts. This need to construct a slum youth "specific mind set" is based on the assumption that high rates of violent crime in port Harcourt water fronts indicates that these areas have disproportionately large populations of violently motivated people. It is this type of thinking which leads to the search for 'places-specific psychological traits', like diffuse aggression, which supposedly motivate an inordinate number of youths to turn violent; however such a search may be ill-advised.

After all, it is widely believed that shanty (ies) in Port Harcourt with high violent crime rates may be overflowing with violent places rather than violent people. For those who see violent places in high crime communities rather than growing on the motivations of the people of these communities.

This emphasis on violent places leads to question about where and when criminal activities occur in communities and what types of places in a community bring violent offenders and their eventual victims together.

However, residential areas, the slums and squatter settlement in Port Harcourt are marked with high rate of violent crime need not be a neighborhood with a surplus of diffusely aggressive residents. Rather, it may be a neighborhood with an undue number of cult related activities, proximity to waterways for easy escape. In the same vein, increase in violent crime in these settlements may not signal a shift in attitudes and motivations of local residents; rather they may mean that new activity (i.e., hostage taking for ransom, a new form of business) have recently opened or a new oil trade has emerged in the area.

When a focus shift to the characteristics of violent places rather than violent people it is also possible to concede that a young male has a greater probability of becoming involved in violent behaviour merely because he lives in such a neighborhood even if he lacks violent motivations. This would mean that violent people might reflect differences in; lifestyles.

We therefore argue, that analysis on difference in violence should probably focus on comparisons based on differences in age and forms of business transactions rather than on presumed differences in motivations, which are more difficult to observed reasoning along this line, it follows that housing is merely an index of achieved life changes not primarily a "cause" Hardoy et al.(1981).The dense population of port Harcourt, which is concentrated in the rural area, tends to migrate into urban centres in large numbers in quest for jobs, better life and modernization due to the poverty and unattractive conditions of their habitat. Such continuous mobility of people from the rural area leads to shortage of labour, particularly in agriculture, which is the main stay of rural economy. Moreover, such continuous drift of the population out of the rural areas discourages effective demand for the provision of infrastructures in those communities. This phenomenon, contributes in accelerating the rate of rural underdevelopment. Okpalanma (1989) noted that the inadequacy of 
housing, water supply, electricity supply, good roads and transportation facilities, employment etc, is directly related to rural urban drift which has created growth of slums, high crime rates and other socio-economic problem, which constitute a cog in the wheel of national progress. He noted that port-Harcourt is the most industrialized city in the southeast region of Nigeria. It has also attracted a great deal of population from the rural areas and other states. The population of the city has increased tremendously as a result. These could be aptly put as the demographic movements that over-stretched the capacity of the city to provide dwelling units to the residents

1. Civil Servants recruited to work in the newly established ministries.

2. Federal government workers whose establishments were extended to Rivers State or upgraded to serve the new state. Some of these were soldiers, police men, customs, immigration, navy, some federal ministries like the ministry of works, finance and others.

3. Fishermen who wanted to benefit from the increased business activities of the oil boom period.

4. Transited passengers from the hinterland and creeks going to other states and other $4 \mathrm{~s}$ coming to the hinterland from those places.

5. Workers employed to work in places of entertainment like hotels which offered lodging to businessmen and travelers. (ibid)

It follows that housing crisis, also resulted in the development of slums and squatter settlement. Slums are areas with dilapidated buildings, where basic facilities have broken down. The house is in a deplorable state of disrepair, it is different from the squatter settlement. In the former, the buildings and the land on which they are built are legal because they were built according to an approved plan but have become dilapidated because of neglect. While squatter settlements are areas with temporary buildings (Ekpenyong) (1999). Put simply, they are spontaneous, peripheral and unserviced settlement which is often threatened with demolition by government. In local parlance they are called water front settlement' which has actually been destroyed by the present administration in river state. This destruction further drew attention to the fact that criminal activities in the state has not ended.

Unarguably, the urban poor live in this squatter settlement, in which occupants are mostly in the informal sector Ogionwo, (1979).this suggests they are unemployed or semi-employed and cannot foot bills expected of them in the more formal sector. Resultantly, there are plausible grounds for believing that unemployment leads to a weakening of social bonds and controls, and hence facilitates the commissions of crime and therefore a higher crime rate, Slattery (1985). Amid certain general trends, there are different cities like plants with their own natural and evolutionary pattern of growth and expansion. But they are also shaped by powerful economic and political forces. Thus, the features, the dimension of city areas and housing types are not a "natural process" they are tied to broader aspects of social organization Ekpenyong (2003).

\section{Statement Of The Problem}

The undue concentration traditionally given to identifying specific motives has caused urbanologist to ignore how housing settlement pattern's violent crime rates may be affected by factors that are observable but have little to do with the motivations of the inhabitants of such water fronts. This focus on settlement based motivations has been driven by the dubious notion that high rates of violent crime in shanty settlement must indicate that there neighborhood are over run with violent persons. This assumption, in turn, leads many to search for reasons why these settlements would produce a surplus of violent persons however, this assumption may be wrong, as high rate of hostage taking and militant related behaviour may be the result of a surplus of violent places rather than violent people. For instance the destruction of Okirika, Abonemma Wharf, Bundum, Nembe, rainbow water fronts settlement in Port Harcourt did not stop the act of hostage taking and militancy in Rivers State. Because shanty town and slum dwellers may have an excess of violent places, perhaps we suggest for future research on differences in violent crime rates between slum or shanty town and the Government Reservation Areas (GRA), to focus on explaining the dynamics of these violent spaces. The paucity in literature which this work intent to fill includes factor like perception of spatial inequality which allows residents of a poor settlement to be lumped together. To argue that such perceptions cause violence leads to problems of over prediction.

\section{OBJECTIVES OF THE STUDY}

The objective of the work is to;

Show the difference between violent people and violent place.

Show how different settlement pattern causes supposed disparities in the collective motivation of crime.

\section{HYPOTHESES}

The following hypotheses will help guide the research design. 
An individuals occupation or income rather than his house, determines his class position and index of achieved life chances not primarily a cause.

\title{
RESEARCH QUESTIONS
}

To further help in the analysis of the findings, the following research question were formulated.

To what extent do the phenomena that affect the distribution of neighbourhood tied to general features of capitalist societies, and at the same time lend an extra dimension to the them?

To what extent is the transition zone in semblance with slums and shanty in Port Harcourt metropolis?

\section{SIGNIFICANCE OF THE STUDY}

The significance of this study is to $\mathrm{x}$-ray and evaluate the intricacies of violent people and violent places as a deciding factor in understanding disparity in crime causation in Port Harcourt. Methodologically, the ideographic approach is used. By this emphasis is placed on getting as close as possible to one subject, in order to grasp, through the exploration of details of his material circumstances and life history, the meaning he gives to the work around him, which determines his social action.

Using Blumner (1969) expression, this method. "Stresses the importance of letting ones subject unfold its nature and characteristics during the process of investigation"

Secondly, the theoretical significance is holistic in its approach, it draws from the human ecology of burgess, park and Mackenzie (1925) which made this idea of invasion, succession and equilibrium the basis of their "theory of concentric urban zones", multiple nuclei sector nuclei.

Thirdly, the practical significance is predicated on its usefulness for proffering solution on housing and crime differential in Port Harcourt. Since research work on housing and crime is ubitiquous, this will help as furtherance for research on differential selections of offenders based on spatial inequality of habitation.

\author{
ASSUMPTION OF THE STUDY \\ The following are given \\ i. $\quad$ Four variables used for this study includes: \\ Crime \\ Income \\ House \\ Class \\ Therefore, it stands that violent people or places is determine by the above variables. \\ ii. Housing acquisition is a function of "income" while class status is the "place" \\ Income (class of residential apartment $)=\alpha_{0}+\alpha 1 \mathrm{CR}(\mathrm{t})+\alpha 2 \mathrm{HO}(\mathrm{t})+\alpha 3 \operatorname{In}(\mathrm{t})+\alpha 4 \mathrm{CL}(\mathrm{t})+\mathrm{U}$ class of residential \\ apartment = slum, shanty or G.R.A.(the dependent variable) $\alpha_{0}$ (bo) =co-efficient of "income" (the independent \\ variable) \\ $\alpha 1 \mathrm{CR}(\mathrm{t})(\mathrm{b} 1 \mathrm{x} 1)=\mathrm{co}-\mathrm{efficient}$ of 'crime. \\ $\alpha 2 \operatorname{Ho}(\mathrm{t})(\mathrm{b} 2 \mathrm{X} 2)=\mathrm{co}-$ efficient of 'housing' \\ $\alpha 3 \operatorname{In}(\mathrm{t})(\mathrm{b} 3 \mathrm{X} 3)=\mathrm{co}-$ efficient of 'income' \\ $\alpha 4 \mathrm{C} 1$ (b4 X4) = co - efficient of 'class' \\ iv. The values placed on them are basically from field work conducted by the researcher
}

\section{OPERATIONALIZATION OF VARIABLES}

For prescriptive clarity, the following concept should be understood thus:

Housing: A residential environment which includes the physical structure which man uses as shelter, as well as necessary services, facilities, equipment and environment needed for the physical and mental health and social well being of both the family and individual.

Note: Crime involving only residents of shanty town is typically bias crimes. Indeed both people living in non shanty town commit crime because they help them to act in terms of consistent beliefs, ideologies or intentions.

\section{THEORETICAL FRAMEWORK}

The theoretical foundation for this work is concentric urban zones theory of Ernest Burgess in 1925. He noted the tendency for most cities to spread outward like ripples on a pond with each zone inhabited by a particular "class" of people. The five zone theory provides a spatial model which when fixed in our study context resembles the idea of invasion, succession and equilibrium. The zones include CBD (Central Business District), zone of transition, zone of working men homes, residential zone, commuters zone. The colonial government first settled around the "town" Borokiri area. This formed the central business district, after tat emerged the zone of transition the Diobu area including D/line and Amadi flat area. This area has the factory zone and forms the "disordered" area that needs to be explained later. The third zone is the zone of 
workingmen's homes, this includes the Rumukwuta, Rumuola, G.R.A and Rumueme are of the city. Basically it includes some part of Obio Akpor Local Government of the State. The residential zone includes the Elekahia housing estate, Nkporgu and mother cat area of the state. The final zone, commuter zone fit into the specification of Eleme Local Government Area with communities such as Akpajo, Alesa and Agbonchia as commuter zone. Oyigbe Local Government Area fall also into this zone.

$\mathrm{Ab}$ initio, the focused on the zone of transition and its apparent "disorganization", its lack of social and moral order, its constant state of influx; is seen with its attendant effect as the least opportunity to stabilize the area of greatest human demoralization and the most likely to "breed" crime and deviance. Hence the mass studies of juvenile gangs prostitution, drug addicts and ethnic groups. There is no gain saying that the origin of the dreadful cult era in port Harcourt had its highest concentration among the Diobu area i.e. the origin growth and development of the dreaded "ice Landers" "Degbam" and "Dewell" in port Harcourt had its rot from Diobu. The water fronts from Elechi, to timber, down to Echue "down (a local parlance for reclaimed, Marchy land in shanty settlement) was the origin of this cult related activities.

This theoretical framework not only bred a who generation of urbanologists but left a legacy of concept that are still popular today- the idea of immigrants "invading" a neighbourhood, of inner city areas breeding crime. Ekpenyong (2003).

\section{Methodology}

Sociological research methods are the techniques an investigator uses systematically together information or data to help answer question about some aspect of society. The variety of methods that can be used is vast with the choice of method depending on the type of question being asked (Ofo, 1999). Objectively, this stresses o fixed correspondence between theoretical paradigm and type of methodology, although according to (Hale, 1990) there is a tendency for certain combination of the theory and method to be common than other. The survey method is used. This approach enables the researcher to detect variation between where one lives, the kind of crime associated with such places and motivation of such people.

\section{SAMPLING TECHNIQUE}

In the house of this research work, the researcher picked those considered to posses the required attributed or information. It presupposes deliberateness in selecting the population elements to sample. It assumes some predetermined criteria. A variant of this methods is what Anikpo (1986:58) called expert opinion. Expert opinion is a situation whereby a person is consulted specifically because he is supposed to be the custodian of a particular type of information to this end the population from which sample is drawn includes urban planners staff of ministry of social welfare and Rehabilitation, resident of shanty towns. Purposive sampling was used.

\section{METHOD OF DATA ANALYSIS}

This research study requires that he drawn hypotheses is empirically tested. To achieve this we use micro fit 4.1 statistical packages.

Data analysis and interpretation

Data on regress and regression

Table 3.1

\begin{tabular}{|l|l|l|l|l|}
\hline Regression & Co-efficient & Standard error & t-ration & P value \\
\hline input & -7729424 & 1806193 & -42791 & .000 \\
\hline X1 & -2235.8 & 16102.0 & -13885 & 0891 \\
\hline X2 & 61787.1 & 19327.0 & 3.1964 & .005 \\
\hline X3 & 34798.0 & 20391.2 & 1.70651 & .104 \\
\hline X4 & -7055.2 & 18.547 .1 & -3804 & .708 \\
\hline R2 & 0.84926 .3 & & & - \\
\hline AER & 26.8120 & & & - \\
\hline F(4,19) & & & & - \\
\hline & & & .001 \\
\hline
\end{tabular}

\section{Interpretation Of Regression Results}

As the preceding regression shows, the partial regression co -efficient of B1X1 of 2235.8 mean that (based on assumption of the study). The average level of crime increase as a result of income that goes down by about 2236. 33 it follows that there is negative relationship between crime and differential spatial settlement.

Secondly, the partial slop co-efficient of 6178.8 means that if the housing b2X2 goes up, the average amount of income amount of income goes up by 61787 , as expected, the relationship between them is positive. This means, there is significant relationship between income and housing choices. 
The partial slop co-efficient of 34798.6 means that holding all things constant, the average amount of choices of houses goes up by about 34798 for income needed to secure a house.

Finally, the partial regression co - efficient b4x4 of 77055.2 mean that holding all things constant, the choice of house goes up by 7055.2 as a result of class, prestige this means income determine the class of houses

In research question 1, the phenomena that affect the distribution of neighbourhood are tied to general features of capitalist societies, and at the same time lend an extra dimension to them, for this reason, of the created environment is an integral feature of capitalist society, then its analysis can be directly derived from an understanding of that form of society as a whole. This tends to negate the study of "urban sociology".

Again in research question 2 the extent to which the transition zone resembles the slims and shanty is supported by the concentric nature of Port Harcourt which the research has grouped under the Diobu and its attendant characteristics. Worthy to note, however, is that the rich did not always move out of the Diobu area as some very rich inhabitants are noticed along Azikiwe Street, the upper side of Abel Jumbo and Ihediohanma Street, all in the Diobu axis.

Percentage of movement between the rich in Diobu

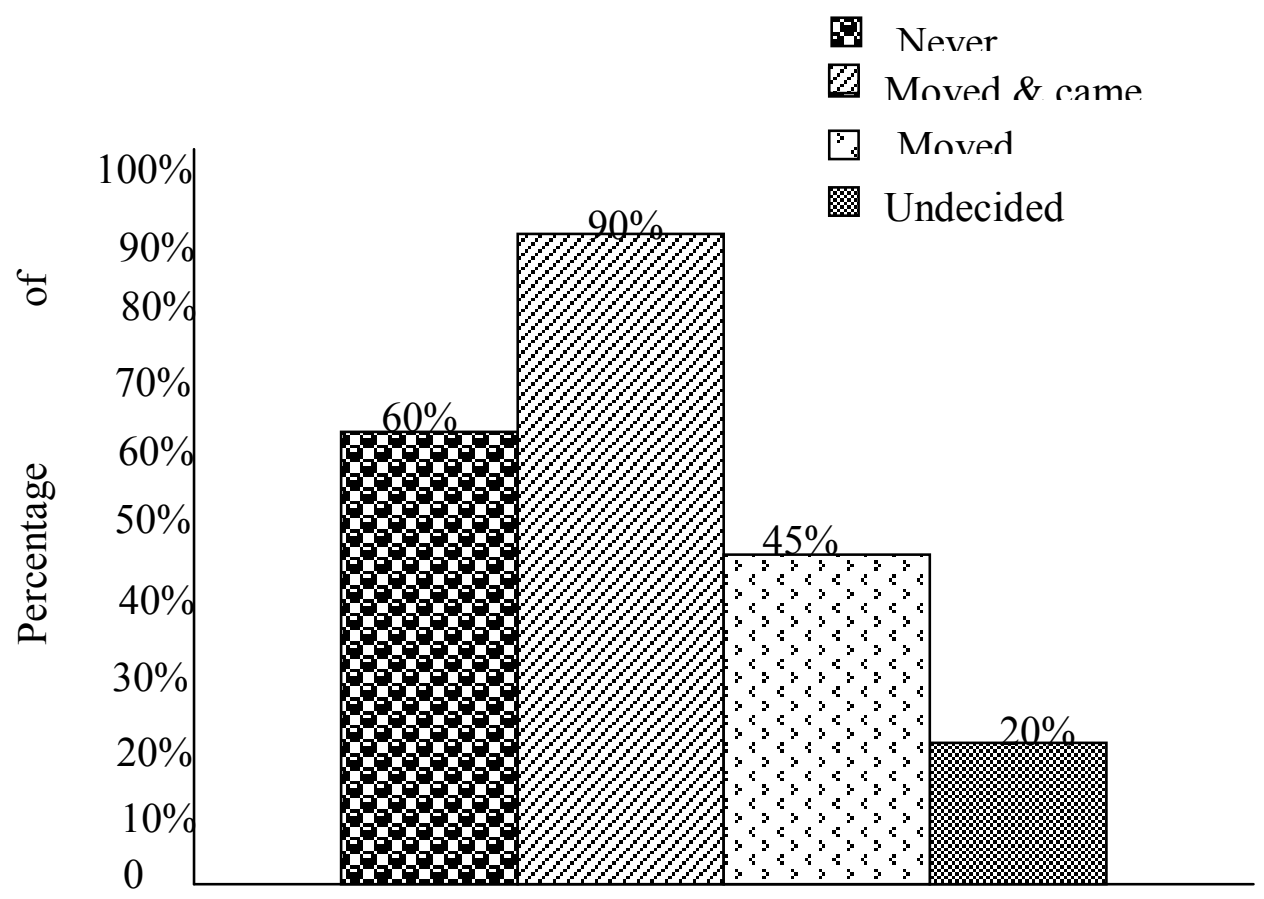

Residents of

This support Ekpenyong's (2003) submission that "There are tremendous variations in the way cities grow and develop. Organization itself does not necessarily follow or depend on industrialization there are alternative ways to urban".

\section{Discussion Of Findings}

The research revealed that it is erroneous to explain crime by analyzing the motives of this involved. Individual psychology should be replace by the many recurring patterns in peoples attitudes and actions, and how these patterns vary across time, place, cultures and social group.

Four variable were used to test the spatial inequality and the determination of how, settlement (place) is a function of income. $\mathrm{H}=\mathrm{f}(1)$ where $\mathrm{H}$ is housing, $\mathrm{f}$ is function and I representing income. Crime and class negate in the autocorrelation. Using DW testing and an AER of 26.8120, further shows that crime is classless in studies area. Sociological import point to the fact that cities have enclaves in which relationships are similar to those in rural areas. Better still, urban life has produce a different kind of community, one that does not depend on people living near one another. The dubious notion that high rates of violent crime in shanty settlement must indicate that there are violent persons has been refuted by findings of the study which reveal that rime in port 
Harcourt is not tied to spatial phenomenon, rather based on the prevalence of certain social forces which determines the dimension and magnitude of crime.

We argue based on finding that individual occupation or income explicates index of achieved life chances. It is not housing that determines behaviour pattern settlement choice but rather the income. Conclusively, our "rate of urbanization which in other parts of the word leads to industrialization has not done that in Nigeria. What we have in Nigeria are massive cities of peasants (emphasis mine) which are badly planned and are lacking in basic infrastructure like electric power, water, rail and road transportation network and security" Muhammad (2009:26).

\section{Conclusion}

In recent time, shanty settlement has been destroyed by the Amaechi-led government in Rivers State. Few reconstruction of this area is going on (especially the Rainbow housing estate). This was informed by the general assumption that specific places harbor criminals, it has been shown from this study that violent people still exits in places term non-shanty. This contradiction still shows the continuous presence of antisocial behaviour even in the hinterland as adumbrated by the current happening. We therefore say that crime is not tied to specific palaces rather to certain conditions, put differently; prevalence of certain social forces determines the dimension and magnitude of crime.

The main policy implication based on the results of the present study is: Investing resources that would raise the standard of living of the people can assist in reducing violence. However, the type of policy that can help in reducing poverty and curbing violence can be achieved when the local people are involved in taking decisions that affect them in any development process. This can go a long way in eliciting confidence among the people and thus, reducing violence than the top down approach currently adopted by government in our area of study.

\section{Policy Recommendation}

The problem of crime and settlement in Port Harcourt appear to have increased over the years. Its lack of adequate tackling is predicated on the creation of social groups based on collective psychological reaction to social deprivations. Therefore, urban poor should be included in government housing development plan and not creating spatial differentiation.

\section{References}

[1]. Anikpo, M.C (1986): Introduction to social research; a methodological guide ABC publisher Enugu.

[2]. Blumner, H (1969): Symbolic interactionism; perspectives and method prentice hall edge.

[3]. Burgess, A (1925): "The concentric theory" cited in Ekpenyong s; "Element of sociology" African Heritage Press Lagos.

[4]. Ekpenyong, S (1992): The city in Africa, African heritage publication.

[5]. Ekpenyong, S (2003): Element of sociology African Hertae publishers Lagos

[6]. Ekpenyong, S (1989): "Housing, the state and poor in Port Harcourt" cities: the international quarterly on urban policy.

[7]. Ekpenyong, S _ (1989): Social inequalities collusion and robbery in Nigerian cities" British journal of criminology.

[8]. Hale, S.M (1990): Controversies in sociology: a Canadian introduction, Firnto; Copp Clark pitman ltd.

[9]. Hardy, J.E Satterthwaite, D (1981): "Shelter, need and response" Chichester, Wiley

[10]. Mohammed, J. (2009): Decade of democratic experiment June 01 the new magazine.

[11]. Ofo, J.E (1994): Research method and statistic in education and social sciences Joja publishes Lagos

[12]. Ogionuno, W Otite, O. (1979): An introduction to sociological studies Heinemann educational book (nig) ltd

[13]. Okpalanma, L.O (1989): "Economic development through population policy: the case of Nigeria", in A journal of the social sciences; vol 2 NWA.

[14]. Slattery, M (1985): Urban sociology Ornskirk, Lancashire, Causeway Press Ltd. 